\title{
Freshwater insects of different feeding guilds ingest microplastics in two Gulf of Guinea tributaries in Nigeria
}

\author{
Emmanuel O. Akindele ${ }^{1,2}$ (1) Sonja M. Ehlers ${ }^{1,3}$ (D) Jochen H. E. Koop ${ }^{1,3}$
}

Received: 26 February 2020 / Accepted: 3 April 2020 / Published online: 23 June 2020

(C) The Author(s) 2020

\begin{abstract}
Plastic pollution has enormous impacts on freshwater and marine ecosystem health, and it is one of the topmost environmental concerns of the current geological period (i.e. the Anthropocene). Thus, the goal of our study was to provide baseline information and bridge the information gap on the occurrence of microplastics (MPs) in African freshwater systems, using two tributaries of the Gulf of Guinea (Ogun and Osun Rivers) in Nigeria as a case study and three freshwater insect species of different feeding guilds as bioindicators. A total of 29 individuals of the insect species were chemically digested and subsequently analysed for MP presence under a digital microscope and a micro-Fourier-transform infrared ( $\mu$ FTIR) spectroscope. Collector-gatherers (Chironomus sp. and Siphlonurus sp.) recorded the highest MP load per gram wet weight, while the predatory Lestes viridis recorded the lowest. The highest diversity of polymers was recorded in Chironomus sp. of Ogun River, i.e. styrene ethylene butylene styrene, acrylonitrile butadiene styrene (ABS), chlorinated polyethylene, polypropylene (PP), and polyester, while two polymers each were recorded in Siphlonurus sp. (i.e. polyester and ABS) and $L$. viridis (i.e. polyester and PP) of Osun River. We conclude that collector-gatherers like Chironomus sp. and Siphlonurus sp. could be best employed as MP bioindicators in freshwater systems. However, their suitability as MP bioindicators should be further investigated in different freshwater ecosystems worldwide.
\end{abstract}

Keywords Chironomids $\cdot$ Damselfly $\cdot$ Mayfly $\cdot$ Gulf of Guinea $\cdot$ Rivers $\cdot$ Synthetic polymer

\section{Introduction}

Reports on the ubiquity of microplastics (MPs) in the biosphere have been well documented, from alpine lakes to deep-sea sediments (e.g. Van Cauwenberghe et al. 2013; Free et al. 2014; Woodall et al. 2014) and from temperate to tropical environments (e.g. Mani et al. 2015; Horton et al. 2018; Nel et al. 2018; Akindele et al. 2019). Aside from primary sources (e.g. abrasives in skin cleansers, toothpaste, shaving cream and related products), another major pathway

Responsible editor: Philippe Garrigues

Emmanuel O. Akindele

eoakindele@oauife.edu.ng

1 Department of Animal Ecology, Federal Institute of Hydrology, Am Mainzer Tor 1, 56068 Koblenz, Germany

2 Department of Zoology, Obafemi Awolowo University, Ile-Ife, Nigeria

3 Institute for Integrated Natural Sciences, University of Koblenz-Landau, 56070 Koblenz, Germany of MPs into aquatic systems of developing nations is through mechanical disintegration of large plastic debris (UNEP 2016). The introduction of such large plastic debris into aquatic systems of many developing nations is usually due to poor waste management practice (Akindele et al. 2019). Such plastics and MPs pose a great danger to wildlife and human populations when introduced into aquatic environments (Galloway 2015; Li et al. 2015; Carbery et al. 2018). Accumulation of MPs by aquatic animals, for instance, could endanger their populations through decreased food consumption, weight loss, decreased growth rate and energy depletion (GESAMP 2015; Rochman et al. 2015; Lusher et al. 2017).

There is evidence that MPs can be transferred from one trophic/biological level to higher levels up to human populations (Farrell and Nelson 2013; Hurley et al. 2017). Such particles have the tendency of being retained in the body of predators for a longer period, thus increasing their susceptibility to MP-related hazards (Lambert and Wagner 2018). Benthic macroinvertebrates have been copiously used in biomonitoring owing to the fact that most members are sessile and their lifespan is long enough for assessment of sitespecific ecological conditions (Rosenberg and Resh 1993; 
Voshell 2002). Recently, there have been studies providing evidence of MP ingestion by freshwater macroinvertebrates. Among such reports are Hurley et al. (2017) on oligochaetes, $\mathrm{Nel}$ et al. (2018) on Diptera/chironomids, Akindele et al. (2019) on gastropods and Windsor et al. (2019) on Ephemeroptera and Trichoptera. Given the fact that freshwater macroinvertebrates have a wide range of feeding guilds (e.g. grazers, shredders, collectors-filterers, collectorgatherers and predators) and ecological niches (Voshell 2002), they could be suitable indicators for assessing MP pollution, both in the water column and in the benthic zone of lotic freshwater systems. High rate of MP ingestion by macroinvertebrates in some UK rivers was recently reported by Windsor et al. (2019), with approximately $50 \%$ of all sampled insects ingesting MPs, and they were recorded in three insect families (i.e. Heptageniidae, Baetidae and Hydropsychidae). Until now, there are two reports of MPs in African freshwater invertebrates (Nel et al. 2018 in South Africa; Akindele et al. 2019 in Nigeria), though only the latter reported MP polymers in their study. Microplastic ingestion by deposit feeders such as ephemeropterans and dipterans has recently been reported by some authors (e.g. Nel et al. 2018; Windsor et al. 2019), and invertebrates such as Chironomus sp. have been strongly recommended as MP bioindicators in freshwater systems (Nel et al. 2018; Scherer et al. 2018). In Nigeria, polyethylene bags have been reported as one of the causes of plastic pollution in aquatic systems, and their ingestion by a freshwater gastropod was most recently reported by Akindele et al. (2019) in Osun River. In view of the foregoing, this study aimed at giving a further insight into the presence and chemical nature (polymers) of MPs in two of the headwaters of the Gulf of Guinea in Nigeria (i.e. Ogun and Osun Rivers), using the representatives of the following aquatic insect orders as bioindicators: Odonata (Lestes viridis), Ephemeroptera (Siphlonurus sp.) and Diptera (Chironomus sp.). The three insect species are part of the benthic community in an aquatic environment, but they belong to two functional feeding guilds. Chironomus sp. and Siphlonurus sp. are collector-gatherers or deposit feeders, while L. viridis is a predator (Voshell 2002). Thus, the study also assessed MP presence and polymers based on two feeding guilds of aquatic invertebrates in the rivers. With respect to these insects, the study also seeks to find out which of the macroinvertebrate taxa or feeding guilds could be best employed as MP bioindicators in (African) freshwater systems.

\section{Materials and methods}

\section{Study area}

The study was conducted in Ogun and Osun Rivers, the two major rivers in the southwestern part of Nigeria. The two rivers are both tributaries of the Gulf of Guinea within the Nigerian territory. Ogun River takes its source from Oyo State and flows through Ogun State into the Lagos Lagoon which borders with the Gulf of Guinea. On the other hand, Osun River takes its source from Ekiti State, flows through Osun, Oyo, and Ogun States, and finally flows into the Lekki Lagoon at Lagos State (Fig. 1). Although the Lekki Lagoon is connected to the Lagos Lagoon, it is not under tidal influence, unlike the Lagos Lagoon which is directly linked with the ocean. In summary, Ogun and Osun Rivers form a confluence at the Lagos Lagoon which in turn connects with the Gulf of Guinea. The two rivers are being jointly managed by the Ogun-Osun River Basin Development Authority (RBDA), which is one of the 12 RBDAs in Nigeria. In the study area of both rivers, there were evidences of large plastic debris in the rivers as well as on their banks, e.g. polyethylene bags, car tyres and fabrics (Fig. 2).

\section{Collection of samples}

In October 2018 (peak of rainy season), aquatic insect samples were collected from the largest and capital cities of both states, i.e. at Abeokuta for Ogun River and Osogbo for Osun River (Fig. 1). Sampling effort was deployed over a stretch of approximately $3 \mathrm{~km}$ from the littoral/sub-littoral sections of each river using a pond net, from eight sampling points at Osun River and six stations at the Ogun River. Individuals of Chironomus sp. were collected from Ogun River, while L. viridis and Siphlonurus sp. were collected from Osun River, respectively. All samples were preserved in the field using $70 \%$ ethanol.

\section{Laboratory analysis}

Based on the method described by Li et al. (2015) and Naji et al. (2018), five individuals of each species were pooled together to constitute a sample. For each species, two samples $(N=2)$ were prepared for analysis, thus consisting of ten individuals $(n=10)$ per species. The only exemption to this was in the case of Siphlonurus sp. where there were two samples of five and four individuals each. The wet weight of each insect was measured using an OHAUS weighing balance (Explorer EX 224). Prior to chemical digestion, insect samples were first rinsed with ultrapure distilled water to get rid of any potential laboratory contaminant, after which samples were immediately transferred into individual glass beakers under a fume cupboard. Twenty (20) $\mathrm{ml}$ each of $\mathrm{KOH}(10 \mathrm{M})$ and $\mathrm{H}_{2} \mathrm{O}_{2}(34.5-36.5 \% \mathrm{v} / \mathrm{v})$ were added to each sample, and the beaker was covered with parafilm. The samples were thereafter shaken on a laboratory shaker (Edmund Buhler 7400 Tübingen) for $120 \mathrm{~h}$. Each sample was neutralized with $7.78 \mathrm{ml}$ formic acid and later filtered using an Anodisc $^{\mathrm{TM}} 47$ (also known as aluminium oxide) Whatman 


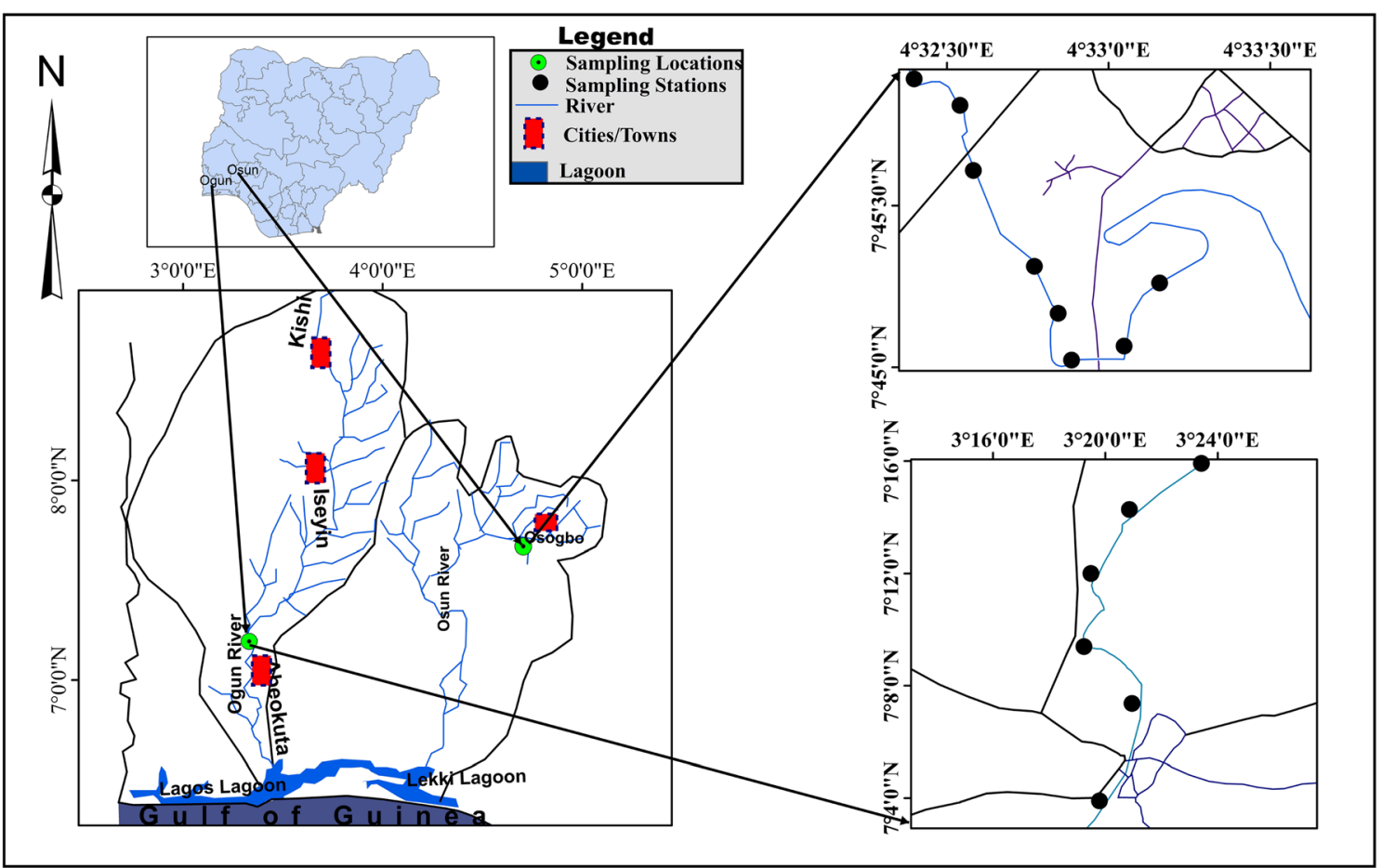

Fig. 1 Map of the study area showing the sampling stations (inset a: map of Nigeria showing the locations of Osun and Ogun Rivers; inset b: map of Ogun and Osun River Basins showing their connections with the Gulf of Guinea

filter paper with $0.2-\mu \mathrm{m}$ pore size. Each filter paper was oven-dried at $50{ }^{\circ} \mathrm{C}$ for $48 \mathrm{~h}$, and it was thereafter viewed under the digital microscope system (VHX-2000 series, Osaka, Japan) for MP occurrence and abundance.

\section{Quality assurance/quality control measures}

At every stage of the analysis, a blank sample was also prepared by employing the same procedure used for the samples.
Fig. 2 Evidences of macroplastic debris in the study area a littoral side of Ogun River $\mathbf{b}$, littoral side of Osun River and $\mathbf{c}$ bank of Ogun River

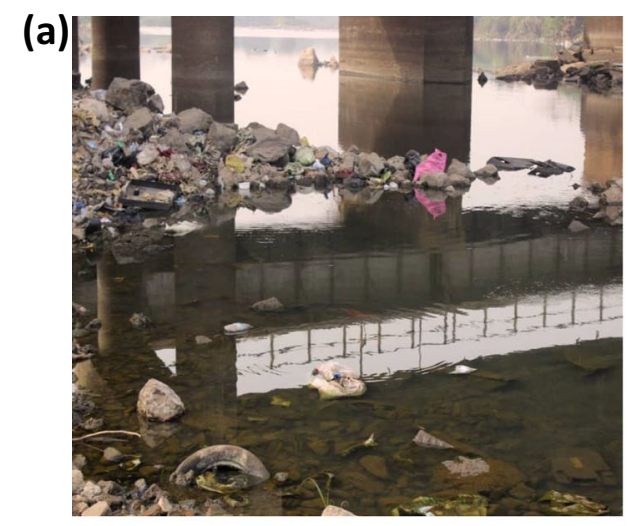

(b)

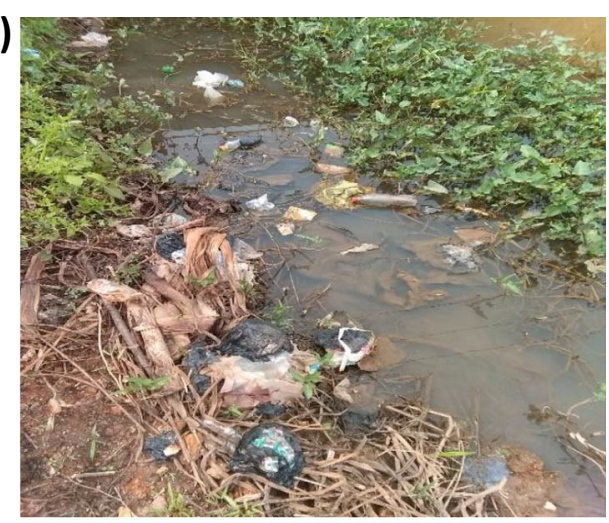

(c)

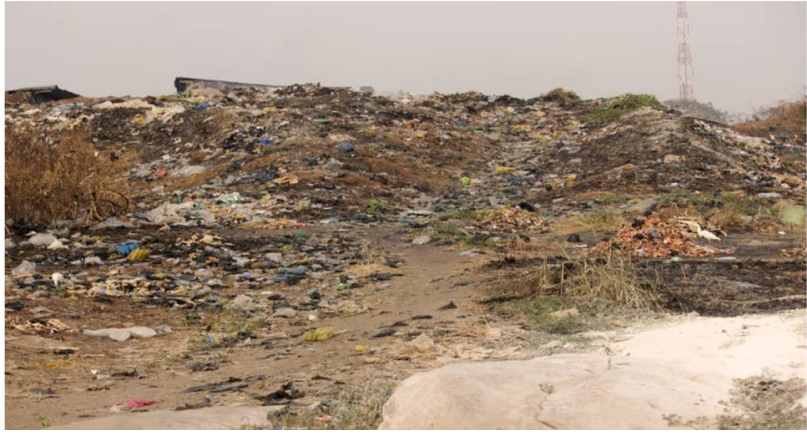


In the same vein, MPs that co-occurred in any sample and the blank were considered to have been exogenously introduced, and such were taken out of the records. Confirmation of each suspected MP and MP polymer determination were done under the micro-Fourier-transform infrared ( $\mu$ FTIR) spectroscope (Hyperion 2000, Bruker, Ettlingen, Germany, see also Fig. 3). The measurements were performed in attenuated total reflectance ( $\mu \mathrm{ATR}$ ) mode with 32 co-added scans and a spectral resolution of $4 \mathrm{~cm}^{-1}$. The software used for polymer identification was OPUS 7.5. Only particles with a hit quality of over 700 were considered as MPs (Ehlers et al. 2019). Soft nitril hand gloves and $100 \%$ cotton laboratory coats were worn during laboratory analysis. All apparatus used were also cleaned and rinsed with ultrapure distilled water at every stage of the analysis.

\section{Statistical analysis}

As all species had different body sizes, we standardized their MP loads as the number of MPs per gramme wet weight for all three species. Then, we checked the data for normality using the Kolmogorov-Smirnov test and checked for homogeneity
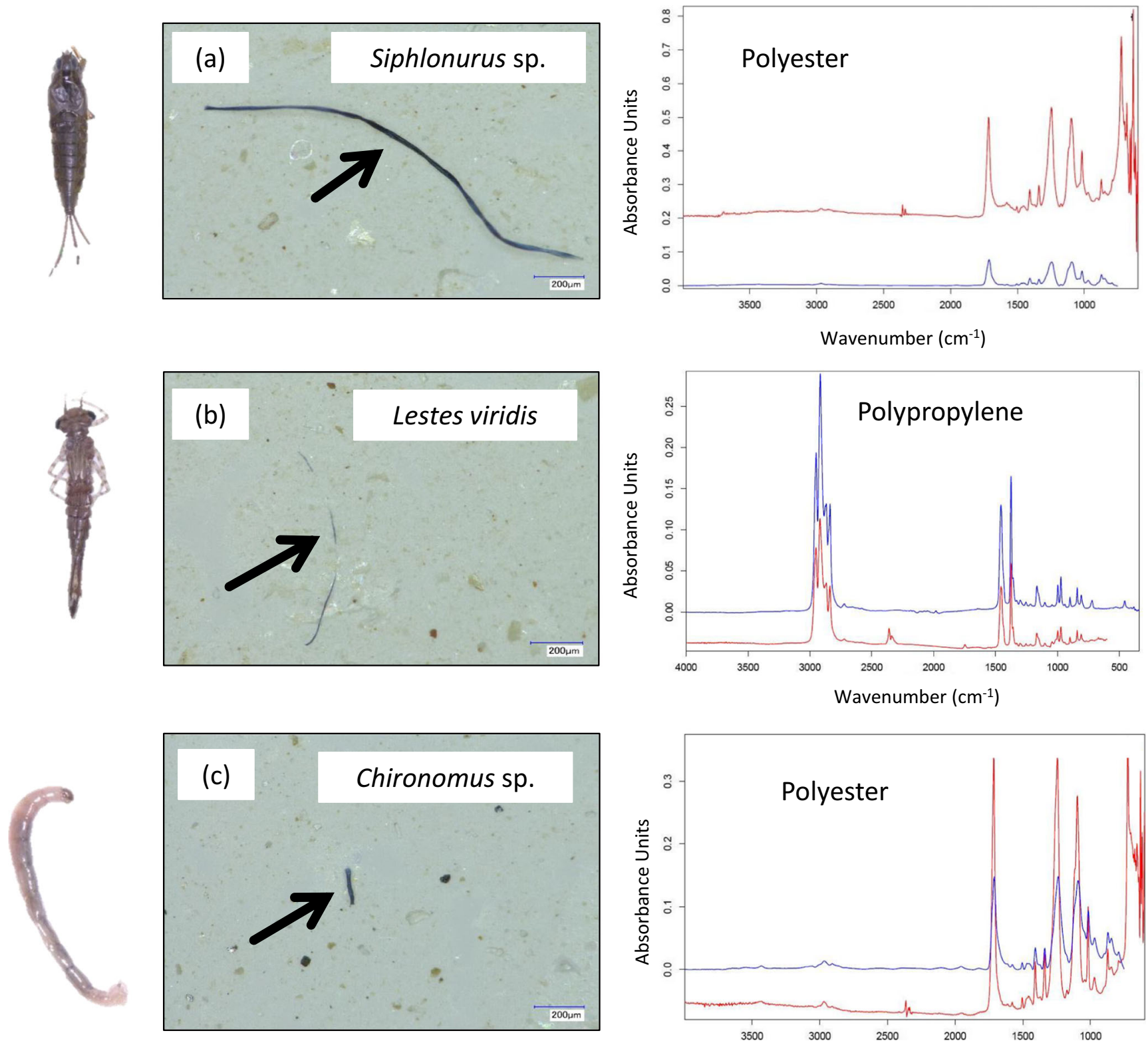

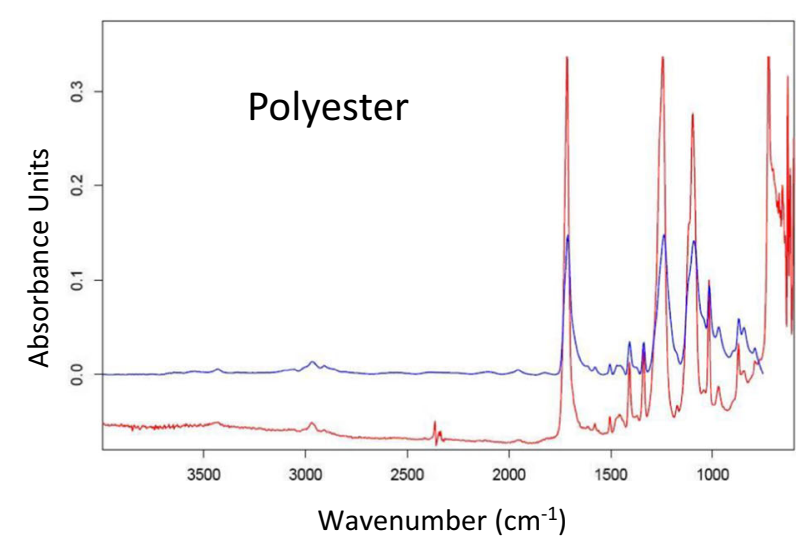

Fig. 3 Representative microplastics in the freshwater insects of Osun and Ogun Rivers, Nigeria. a Siphlonurus sp., b Lestes viridis and c Chironomus sp. (The red spectrum is that of the $\mu$ FTIR measurement, while the blue spectrum is the reference spectrum from the Bruker database) 
of variances using Cochran's $\mathrm{C}$ test. As the assumptions for an ANOVA were met, we then performed a one-factorial ANOVA. All statistical tests were performed in Statistica 13 (Tulsa, OK, USA).

\section{Results}

Comparatively, Chironomus sp. was the smallest insect in this study based on wet body weight which ranged from 5.6 to $17.5 \mathrm{mg}$. The wet body weight of $L$. viridis ranged from 17.7 to $33.8 \mathrm{mg}$. Siphlonurus $\mathrm{sp}$. was the biggest and its weight ranged from 15.1 to $82.2 \mathrm{mg}$. Two types of microplastics were recorded in this study, namely, fibres and fragments. The two MP types were recorded in Chironomus and Siphlonurus sp., while only one (i.e. fibre) was recorded in L. viridis (Table 1). Fibre was recorded in all the species, and it dominated MP composition in each case. The least dominance (55.2\%) of fibre was recorded in Chironomus sp. and the highest $(100 \%)$ in L. viridis. Fragment, which occurred only in two species, recorded the lowest (17.4\%) MP dominance in Siphlonurus sp., while the highest $(44.8 \%)$ was in Chironomus sp.. The following trend was observed among the species with respect to MP load per wet weight: Chironomus sp. $>$ Siphlonurus sp. $>$ L. viridis. The ANOVA indicated a significant difference between the species regarding MP load per gram wet weight, i.e. $\mathrm{F}(2,3)=22.14, p=$ 0.016 . Tukey's HSD showed that the MP load per gramme wet weight in Chironomus sp. was significantly different from the load in Siphlonurus sp. $(p=0.024)$ and L. viridis $(p=$ $0.019)$, respectively. There was no difference in MP load per gramme wet weight between $L$. viridis and Siphlonurus sp. $(p=0.894)$. Images of some recorded MPs and their corresponding polymer spectra are shown in Fig. 3. MicroFTIR analysis revealed the following MP polymers in Osun River: polyester (in both L. viridis and Siphlonurus sp.), polypropylene (in L. viridis only) and acrylonitrile butadiene styrene (ABS) (in Siphlonurus sp. only). In Chironomus sp. of Ogun River, the following MP polymers were recorded: styrene ethylene butylene styrene (SEBS), ABS, chlorinated polyethylene, polypropylene and polyester MPs.

\section{Discussion}

In this study, MPs were recorded in different orders of insects as well as different feeding guilds, thus suggesting that aquatic animals of different taxonomic categories or ecological niches may be predisposed to MP pollutants. Chironomus sp. had a significantly higher MP body burden per gramme wet weight than the other two species. Chironomus sp. is a collectorgatherer with the capacity to feed on deposited organic materials on stream or riverbeds (Voshell 2002; Nel et al. 2018). Unlike the water column, this section of an aquatic system has a higher retention capacity and is regarded as the most important sink of pollutants in freshwater environments (Morin et al. 2007). Primary or secondary MPs could end up in any of the following ways in river systems: (1) they could drift with the water mass into adjacent oceans or lakes; (2) like other suspended solids, they could settle on the riverbed when flow velocity is too low to keep them in suspension (Voshell 2002); and (3) they could outrightly be ingested by aquatic animals as previously reported by several authors (e.g. Rosenkranz et al. 2009; Akindele et al. 2019; Windsor et al. 2019). The suitability of deposit feeders, particularly Chironomus sp., as MP bioindicator has also been reported by Nel et al. (2018) in a South African river system. Deposit feeders may therefore be suitable as MP bioindicators in lotic freshwater systems since they are not only site-specific, but they can also indicate impacts over a period of time. In previous lab experiments, it has been shown that MP ingestion can affect the life history (Silva et al. 2019) and survival, growth and emergence (Ziajahromi et al. 2018) in chironomid larvae. Hence, those insects may also be negatively impacted by MP in the field. Other evidences of low physiological fitness in aquatic invertebrates on account of MPs include reduced filtering or feeding capacity in blue mussel (Mytilus edulis) and reduced reproductive output in a species of copepod (Calanus helgolandicus) (Wegner et al. 2012; Cole et al. 2013). Ingested MPs in aquatic animals could also lead to transfer of hydrophobic and persistent organic pollutants (e.g. dichlorodiphenyltrichloroethane, polychlorinated biphenyls and dioxins) to higher trophic levels in the food chain, since MPs serve as vectors for such transfer (Teuten et al. 2009). Thus, MPs could pose a threat to the sustenance of aquatic biodiversity considering their
Table 1 Microplastic loads (per gram wet weight) in the three insect species of Ogun and Osun Rivers, Nigeria

\begin{tabular}{|c|c|c|c|c|c|}
\hline \multirow[t]{2}{*}{ Species } & \multirow[t]{2}{*}{$\mathrm{N}$} & \multirow{2}{*}{$\begin{array}{l}\text { *Number of pooled } \\
\text { individuals }\end{array}$} & \multicolumn{3}{|c|}{ MP load per gram wet weight (mean \pm SEM) } \\
\hline & & & Fibre & Fragment & Total \\
\hline Lestes viridis & 2 & $* 10(5+5)$ & $43.29 \pm 43.29$ & 0 & $43.29 \pm 43.29$ \\
\hline Siphlonurus sp. & 2 & $* 9(5+4)$ & $51.81 \pm 1.13$ & $10.54 \pm 4.66$ & $62.36 \pm 3.53$ \\
\hline Chironomus sp. & 2 & $* * 10(5+5)$ & $179.43 \pm 85.82$ & $112.33 \pm 59.28$ & $291.76 \pm 26.55$ \\
\hline
\end{tabular}

*Number of pooled individuals from the eight stations in Osun River; **Number of pooled individuals from the six stations in Ogun River 
physiological and ecotoxicological implications when ingested by animals.

Like in many MP studies, fibres dominated MP composition in both rivers and the three insects. Among other causal factors, Browne et al. (2011) reported that a key important source of microplastic fibres appears to be through sewage contaminated by fibres from washing clothes. They also reported that a garment can produce $>1900$ fibres per wash or $>$ 100 fibres per litre of effluent. Incidentally, polyester occurred in both rivers, and this has been linked to sources such as clothing, automotive tyre cords and beverage containers (Harper 1996; Gowariker et al. 2001). Introduction of polyester MP could be linked to direct washing of clothes inside streams and rivers which is a common practice by many locals in many parts of Nigeria and Africa, due to poor economies and lack of domestic water supply, especially in rural and semi-urban areas. In addition, evidence of worn-out tyres was also sighted inside Ogun River from which the Chironomus sp. was collected (Fig. 2a). Sources of other MP polymers recorded in this study can also be related to prevalent plastic sources in Nigeria. These include the following: polypropylene, e.g. fabrics, biscuit wrappers, rope, bottle caps and drinking straws; ABS, e.g. highway safety devices and toys; SEBS, e.g. toy products, shoe soles, road paving and roofing applications; and chlorinated polyethylene which is often used in conjunction with polyvinyl chloride and has a wide range of applications in construction (Harper 1996; Gowariker et al. 2001; GESAMP 2015). The heterogeneity of MP types recorded in these rivers as well as the insects could be a reflection of various applications of plastics in the respective river basins. Going by the level of plastic deposits on the riverbanks as well as in the rivers, it is also most likely that these MPs are mostly derived secondarily through fragmentation of larger plastic debris and through factors such as wind, ultraviolet radiation and animal digestion (UNEP 2016).

In conclusion, this is the first study to show that MPs can be ingested by larval odonatans, insects that are threatened in many countries worldwide. Collector-gatherers seemed to record more diverse polymers than predatory insects in this study. However, future studies should seek to test further if collector-gatherers (e.g. Chironomus sp. and Siphlonurus sp.) could be best employed as MP bioindicators among other macroinvertebrate taxa, by using a larger sample size. It would also be important to consider MP analysis in both water columns as well as in riverbeds, from which MPs are ingested by the animals.

Acknowledgements Open Access funding provided by Projekt DEAL. Special thanks also go to the German Federal Institute of Hydrology, Koblenz, for providing laboratory facilities and library resources during the study.

Authorship contribution statement Emmanuel O. Akindele: Project design, field sampling, laboratory analysis, and writing original draft. Sonja M. Ehlers: Formal analysis, $\mu$ FTIR analysis, review and editing. Jochen H.E. Koop: Project design, review and editing.

Funding information This study was supported by the German Academic Exchange Service visiting scholarship (grant number 91690476) awarded to the first author.

\section{Compliance with ethical standards}

Conflict of interest The authors declare that they have no conflict of interest.

Open Access This article is licensed under a Creative Commons Attribution 4.0 International License, which permits use, sharing, adaptation, distribution and reproduction in any medium or format, as long as you give appropriate credit to the original author(s) and the source, provide a link to the Creative Commons licence, and indicate if changes were made. The images or other third party material in this article are included in the article's Creative Commons licence, unless indicated otherwise in a credit line to the material. If material is not included in the article's Creative Commons licence and your intended use is not permitted by statutory regulation or exceeds the permitted use, you will need to obtain permission directly from the copyright holder. To view a copy of this licence, visit http://creativecommons.org/licenses/by/4.0/.

\section{References}

Akindele EO, Ehlers SM, Koop JHE (2019) First empirical study of freshwater microplastics in West Africa using gastropods from Nigeria as bioindicators. Limnologica 78:125708

Browne MA, Crump P, Niven SJ, Teuten E, Tonkin A, Galloway T, Thompson R (2011) Accumulation of microplastics on shorelines worldwide: sources and sinks. Environ Sci Technol 45:9175-9179

Carbery M, O'Connor W, Palanisami T (2018) Trophic transfer of microplastics and mixed contaminants in the marine food web and implications for human health. Environ Int 115:400-409

Cole M, Lindeque P, Fileman E, Halsband C, Goodhead R, Moger J, Galloway TS (2013) Microplastic ingestion by zooplankton. Environ Sci Technol 47(12):6646-6655

Ehlers SM, Manz W, Koop JHE (2019) Microplastics of different characteristics are incorporated into the larval cases of the freshwater caddisfly Lepidostoma basale. Aquat Biol 28:67-77

Farrell P, Nelson K (2013) Trophic level transfer of microplastic: Mytilus edulis (L.) to Carcinus maenas (L.). Environ Pollut 177:1-3

Free CM, Jensen OP, Mason SA, Eriksen M, Williamson NJ, Boldgiv B (2014) High-levels of microplastic pollution in a large, remote, mountain lake. Mar Pollut Bull 85(1):156-163

Galloway TS (2015) Micro- and nano-plastics and human health. In: Bergmann M, Gutow L, Klages M (eds) Marine anthropogenic litter. Springer International Publishing, pp 343-366

GESAMP (2015) Sources, fate and effects of microplastics in the marine environment: a global assessment. In: Kershaw PJ (ed) (IMO/FAO/ UNESCO-IOC/UNIDO/WMO/IAEA/UN/UNEP/UNDP Joint Group of Experts on the Scientific Aspects of Marine Environmental Protection). Rep. Stud. GESAMP No. 90, 96

Gowariker VR, Viswanathan NV, Sreedhar J (2001) Polymer science. New Age International (P) Limited Publishers, Bangalore

Harper CA (1996) Handbook of plastic elastomers and composites, 3rd edn. McGrawHill Professional Book, New York

Horton AA, Jürgens MD, Lahive E, van Bodegom PM, Vijver MG (2018) The influence of exposure and physiology on microplastic 
ingestion by the freshwater fish Rutilus rutilus (roach) in the River Thames, UK. Environ Pollut 236:188-194

Hurley RR, Woodward JC, Rothwell JJ (2017) Ingestion of microplastics by freshwater Tubifex worms. Environ SciTechnol 51:12844-12851

Lambert S, Wagner M (2018) Microplastics are contaminants of emerging concern in freshwater environments: an overview. In: Lambert $\mathrm{S}$, Wagner M (eds) Freshwater microplastics-emerging, contaminants? The handbook of environmental chemistry, pp 101-124 ISBN 978-3-319-61614-8

Li J, Yang D, Li L, Jabeen K, Shi H (2015) Microplastics in commercial bivalves from China. Environ Pollut 207:190-195

Lusher A, Welden N, Sobral P, Cole M (2017) Sampling, isolating and identifying microplastics ingested by fish and invertebrates. Anal Methods 9:1346-1360

Mani T, Hauk A, Walter U, Burkhardt-Holm P (2015) Microplastics profile along the Rhine River. Sci Rep 5:17988

Morin S, Vivas-Nogues M, Duong TT, Boudou A, Coste M, Delmas F (2007) Dynamics of benthic diatom colonization in a cadmium/zinc-polluted river (RiouMort, France). Fund Appl Limnol 168:179-187

Naji A, Nuri M, Vethaak AD (2018) Microplastics contamination in molluscs from the northern part of the Persian Gulf. Environ Pollut 235:113-120

Nel HA, Dalu T, Wasserman RJ (2018) Sinks and sources: assessing microplastic abundance in river sediment and deposit feeders in an Austral temperate urban river system. Sci Total Environ 612:950 956

Rochman CM, Tahir A, Williams SL, Baxa DV, Lam R, Miller JT, Teh FC, Werorilangi S, Teh SJ (2015) Anthropogenic debris in seafood: plastic debris and fibres from textiles in fish and bivalves sold for human consumption. Sci Rep 5(1):14340

Rosenberg D, Resh V (1993) Freshwater biomonitoring and benthic macroinvertebrates. Chapman and Hall, New York

Rosenkranz P, Chaudhry Q, Stone V, Fernandes TF (2009) A comparison of nanoparticle and fine particle uptake by Daphnia magna. Environ Toxicol Chem 28(10):2142-2149

Scherer C, Weber A, Lambert S, Wagner M (2018) Interactions of microplastics with freshwater biota. In Wagner M, Lambert S (eds) Freshwater Microplastics Emerging Environmental . Contaminants? The Handbook of Environmental Chemistry, pp. 153-180 ISBN 978-3-319-61614-8
Silva CJM, Silva ALP, Gravato C, Pestana JLT (2019) Ingestion of smallsized and irregularly shaped polyethylene microplastics affect Chironomus riparius life-history traits. Sci Total Environ 672: 862-868

Teuten EL, Saquing JM, Knappe DRU, Barlaz MA, Jonsson S, Bjorn A, Rowland SJ, Thompson RC, Galloway TS, Yamashita R, Ochi D, Watanuki Y, Moore C, Pham HV, Tana TS, Prudente M, Boonyatumanond R, Zakaria MP, Akkhavong K, Ogata Y, Hirai H, Iwasa S, Mizukawa K, Hagino Y, Imamura A, Saha M, Takada $H$ (2009) Transport and release of chemicals from plastics to the environment and to wildlife. Philos Trans R Soc B 364(1526): 2027-2045

UNEP (2016) Marine plastic debris and microplastics - global lessons and research to inspire action and guide policy change. United Nations Environment Programme, Nairobi http://www. sciencedirect.com/science/article/pii/S0025326X14003622

Van Cauwenberghe L, Vanreusel A, Mees J, Janssen CR (2013) Microplastic pollution in deep-sea sediments. Environ Pollut 182: 495-499

Voshell JR (2002) A guide to common freshwater invertebrates of North America. The McDonald and Woodward Publishing Company, Granville

Wegner A, Besseling E, Foekema EM, Kamermans P, Koelmans AA (2012) Effects of nanopolystyrene on the feeding behavior of the blue mussel (Mytilus edulis L.). Environ Toxicol Chem 31(11): 2490-2497

Windsor FM, Tilley RM, Tyler CR, Ormerod SJ (2019) Microplastic ingestion by riverine macroinvertebrates. Sci Total Environ 646: 68-74

Woodall LC, Sanchez-Vidal A, Canals M, Paterson GLJ, Coppock R, Sleight V, Calafat A, Rogers AD, Narayanaswamy BE, Thompson $\mathrm{RC}$ (2014) The deep sea is a major sink for microplastic debris. $\mathrm{R}$ Soc Open Sci 1:140317

Ziajahromi S, Kumar A, Neale PA, Leusch FDL (2018) Environmentally relevant concentrations of polyethylene microplastics negatively impact the survival, growth and emergence of sediment-dwelling invertebrates. Environ Pollut 236:425-431

Publisher's note Springer Nature remains neutral with regard to jurisdictional claims in published maps and institutional affiliations. 